\title{
Greenhouse gas emissions in conversion from extensive pasture to other agricultural systems in the Andean region of Colombia
}

\author{
Amanda Silva Parra ${ }^{1}$ Eduardo Barretto de Figueiredo ${ }^{2}$. \\ Ricardo Oliveira de Bordonal $^{3} \cdot$ Mara Regina Moitinho $^{1}$ • \\ Daniel De Bortoli Teixeira ${ }^{1}$ Newton La Scala Jr. ${ }^{1}$
}

Received: 18 February 2017/ Accepted: 26 September 2017/Published online: 3 October 2017

(C) Springer Science+Business Media B.V. 2017

\begin{abstract}
The challenge of agricultural sector is to reduce greenhouse gas (GHG) emissions while increasing food, fiber and energy production without jeopardizing environmental integrity. In the Andean zone of Colombia, there is a growing need to develop GHG mitigation techniques associated with milk production. The present study focuses on GHG emissions and potential sinks associated with milk production scenarios in the Andean zone of Colombia. The scenarios considered were as follows: conventional agriculture of Pennisetum clandestinum in rotation with potatoes (PRP), improved pastures of Lolium multiflorum (IP) and silvopastoral system of P. clandestinum in association with Acacia decurrens and Trifolium repens (SPS). Based on the IPCC (Guidelines for national greenhouse gas inventories. The intergovernmental panel on climate change, Institute for Global Environmental Strategies, Kanagawa, 2006. http://www.ipcc-nggip.iges.or.jp/ support/Primer_2006GLs.pdf) methodologies, the annual GHG emissions considering a 6-year production cycle included agricultural sources and gasoline consumption related to the most important agricultural phases in the field, and a potential for soil carbon accumulation and biomass carbon fixation in all the studied scenarios. The lowest GHG emissions were estimated in PRP scenario (3684 $\mathrm{kg} \mathrm{CO}_{2}$-eq ha ${ }^{-1}$ year $^{-1}$ ), which also presented additional emissions because of soil carbon losses beyond the lower milk productivity. Highest GHG emissions were observed in IP scenario $\left(7711 \mathrm{~kg} \mathrm{CO}_{2}\right.$-eq ha ${ }^{-1}$ year $^{-1}$ ), which exhibited the highest milk productivity and a considerable potential for soil carbon accumulation that could help to offset its emissions. Nevertheless, SPS scenario,
\end{abstract}

Mara Regina Moitinho

maramoitinho@gmail.com

1 Department of Exact Sciences, College of Agricultural and Veterinarian Sciences, São Paulo State University, FCAV/UNESP), Via de Acesso Prof. Paulo Donato Castellane s/n, Jaboticabal, SP 14883-292, Brazil

2 Department of Rural Development, Centro do Ciências Agrárias, Federal University of São Carlos (UFSCar), Rodovia Anhanguera, km 174, Araras, SP, Brazil

3 Brazilian Bioethanol Science and Technology Laboratory/Brazilian Center for Research in Energy and Materials (CTBE/CNPEM), Rua Giuseppe Máximo Scolfaro 10000, Polo II de Alta Tecnologia, Campinas, SP 13083-970, Brazil 
which had milk productivity close to that of IP, presented the highest potential to offset the total GHG emission (4878 $\mathrm{kg} \mathrm{CO}_{2}$-eq ha ${ }^{-1}$ year $^{-1}$ ) because of soil carbon accumulation and biomass carbon fixation in trees. This study contributed to indicate management strategies that should be prioritized to mitigate the main sources of GHG emission in the extensive and intensive dairy cattle production in the Andean region of Colombia.

Keywords Biomass and soil carbon sequestration · Milk production · Agricultural intensification · Climate change · GHG mitigation · Global warming · Grassland · Trees

\section{Introduction}

According to Smith et al. (2014), the Agriculture, Forestry and Other Land Use (AFOLU) sector was responsible for approximately a quarter $\left(\sim 10-12 \mathrm{GtCO}_{2} \mathrm{eq} \mathrm{yr}^{-1}\right)$ of anthropogenic greenhouse gas (GHG) emissions mainly from deforestation and agricultural emissions from livestock, soil and nutrient management, of which annual GHG emissions from agricultural production in 2000-2010 were estimated at 5.0-5.8 $\mathrm{GtCO}_{2} \mathrm{eq} \mathrm{yr}^{-1}$. These authors identified that opportunities for mitigation in this sector include supply-side and demand-side options, in which emissions from land-use change (LUC), land management and livestock management can be reduced, terrestrial carbon stocks can be increased by sequestration in soils and biomass, and emissions from energy production can be saved through the substitution of fossil fuels by biomass.

Previous studies have indicated that no-tillage cropping practices and the recuperation of degraded pasture have both led to increased soil organic carbon (SOC) stock in different tropical regions (Corazza et al. 1999; Silva et al. 2004; La Scala et al. 2012; De Figueiredo et al. 2017). Accordingly, changes in land use and different crop and soil management in the Colombia Andean Zone can effectively contribute for the reduction of GHG through the introduction of more sustainable agroforestry systems, presenting their respective GHG balance and identifying better management systems with lower emissions and higher yields.

It is worth mentioning that approximately 14,000 ha in the Savannah of the city of Túquerres in southern Colombia are intended for grazing dairy cattle that consists of extensive systems of Pennisetum clandestinum (Solarte et al. 2006), which are currently in the process of degradation (Silva et al. 2010), with low forage diversity and low productivity (Silva et al. 2010). On these areas, crop and livestock productions are closely linked to the traditional mixed conventional agricultural system, characterized by the degraded pastures of $P$. clandestinum in rotation with potatoes (Guerrero 1998), or are completely changed each year to plant improved pastures of Lolium multiflorum (Bernal 1994).

Several studies have shown that, to support global demand for food, fiber and bioenergy, it is critical to improve the quality of pasturelands and adopt best management practices as a key strategy to avoid additional land degradation (Costa et al. 2015; Papanastasis et al. 2015; Smith et al. 2015). In contrast, conventional agricultural systems have been intensively adopted with high utilization of agricultural inputs such as soluble fertilizers, primarily nitrogen (Smith et al. 1997; Oenema et al. 1997; McGrath et al. 1998) and pesticides (Boul et al. 1994), which also results in higher direct and indirect GHG emissions (Robertson et al. 2000; Saggar et al. 2007).

However, the recent adoption of silvopastoral systems has been reported as resulting in positive aspects when compared with conventional systems in the Andean zone, with 
increases in milk productivity (Correa et al. 2008; Aguilar et al. 2009), efficient use of nitrogen through biological fixation (Medina et al. 2008), and restoring the potential for soil carbon sequestration and biomass carbon fixation (Giraldo et al. 2008), including GHG mitigation (Grainger et al. 2009). Evaluating and characterizing $\mathrm{FCO}_{2}$ (soil $\mathrm{CO}_{2}$ flux) in degraded and managed pasture areas and describing their spatial-temporal variability and any correlation with possible controlling factors, Figueiredo et al. (2017a) concluded that degraded pasture area released significantly more $\mathrm{CO}_{2}-\mathrm{C}$ comparing with the well-managed pasture. This indicates that the introduction of best management practices in pasture areas is an important strategy to reduce additional soil $\mathrm{CO}_{2}-\mathrm{C}$ losses and thereby contributes to soil $\mathrm{C}$ accumulation in those areas.

Despite several efforts for the introduction of more sustainable agricultural systems in Colombia, there is still some resistance in adopting silvopastoral systems in the tropics (Fedegan-Cipav 2010; FAO 2010), which could be supported by studies that present positive outcomes not only from the GHG balance but also from a more suitable introduction of these agricultural systems. Therefore, the objective of this study was to estimate the GHG emissions and potential C sinks, considering the emission sources and sinks related to conventional agriculture, improved pasture and silvopastoral production systems in the Nariño region, Colombia, in order to identify a promising silvopastoral system toward greater sustainability for tropical conditions.

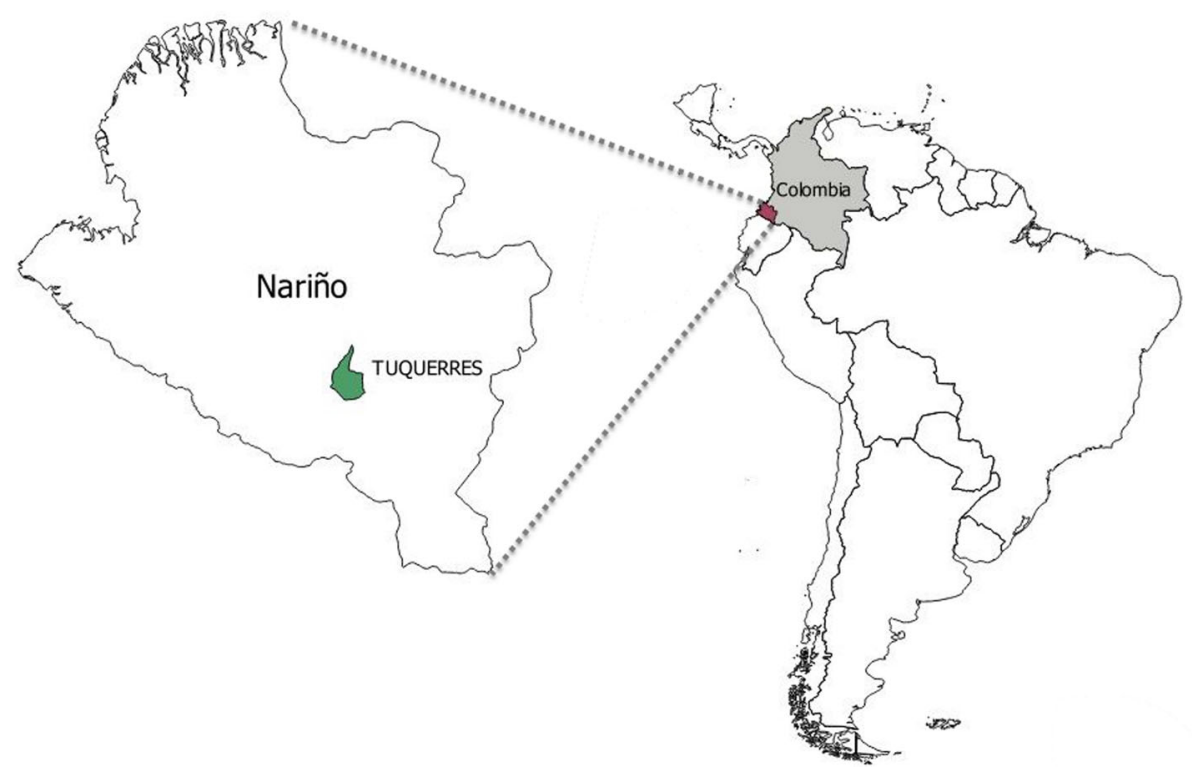

Fig. 1 Schematic picture of the evaluated scenarios located in Túquerres city, Nariño state, Colombia 


\section{Materials and methods}

\subsection{Location and production scenarios}

The systems considered in this study refer to the milk production areas located in the Andean region, city of Túquerres, state of Nariño, southwest Colombia (Fig. 1). The pasture areas in this region are located at around $3070 \mathrm{~m}$ above sea level with geographical coordinates $1^{\circ} 05^{\prime} 14^{\prime \prime} \mathrm{N}$ and $77^{\circ} 37^{\prime} 08^{\prime \prime} \mathrm{W}$. It is one of the highest plateaus of the country exceeding $2900 \mathrm{~m}$ above sea level, with an average temperature of $8-12{ }^{\circ} \mathrm{C}$, average annual rainfall around $900 \mathrm{~mm}$, and weather classification of Dfb, according to the Köppen climate classification, cold temperate climate with no dry season and with tempered summer (Köppen 1948).

Our database is related to the real production scenarios applied in the Andean zone of Colombia, considering the practices conducted with animals, soil management and agricultural activities related to agricultural systems described in the following sections. The production scenarios considered are: (1) conventional agriculture under pastures of $P$. clandestinum in rotation with potatoes (PRP); (2) improved pastures of L. multiflorum (IP); and (3) silvopastoral system represented by pastures of $P$. clandestinum in combination with Acacia decurrens and Trifolium repens (SPS). All scenarios investigated run in a 6-year cycle, with PRP having a crop sequence of potatoes, pasture, and animal grazing in the first and fourth year and pasture and animal grazing during the other years. In the case of IP scenario, animal grazing and pasture are considered during all cycles. But in the case of SPS scenario, animal grazing with pasture associated with Acacias trees run in all years during the 6-year cycle.

Table 1 presents the details associated with the zootechnical and agronomic parameters of the production scenarios of Andean region considered in this study. The crop sequence considered in the PRP scenario is potatoes in monoculture with two cycles per year, conventional soil tillage, high input of fertilizers and pesticides, high residue production (Guerrero 1998), followed by pasture of $P$. clandestinum, extensive systems with degraded pastures using 2 years for grazing production (Guerrero 1998), and low inputs of fertilizers and having low milk productivity, with rotational grazing of animals every 90 days (Bernal 1994). Around $10 \%$ of pastures with P. clandestinum (1400 ha) are used in the Andean zone for dairy cattle (Solarte et al. 2006). The intensification applied in the unfertilized rotations of pastures in PRP had to be sustained through the extraction of soil reserves.

In the IP scenario, the agronomic characteristics are intensive system with high grass production, high residue production from pasture that is replanted every year (Bernal 1994) by using conventional tillage, with high demand for nitrogen fertilizers and concentrates as animal supplementation, and high productivity of milk, with rotational grazing of animals every 45 days (Bernal 1994). Around 1500 ha has been converted to this production system in the Andean region in the last years (Solarte et al. 2006).

The silvopastoral system, i.e., the SPS scenario, is characterized by the introduction of grass species with higher productivity in 6 years consecutively with A. decurrens trees, whose fodder comprising leaves and stems is used for grazing and animal feeding (Giraldo et al. 2008; Giraldo and Bolivar 2004). The trees are used as fence for surrounding the pasture area, which are spaced $1 \mathrm{~m}$ apart, resulting in a total of 400 trees ha $^{-1}$ (Giraldo and Bolivar 2004). This system also includes soil management by subsoiling (Noreña 2011) and planting of clover forage legume (Sanchez and Villaneda 2009). Biological nitrogen fixation in SPS displaces the use of synthetic nitrogen fertilizers (Naranjo et al. 2012) with 
Table 1 Characterization of the production systems considered: PRP-conventional agriculture with pastures of Pennisetum clandestinum in rotation with potatoes; IP_improved pasture of Lolium multiflorum; SPS - silvopastoral systems represented by pastures of Pennisetum clandestinum in consortium with Acacia decurrens and Trifolium repens presented in the Andean region of Colombia with zootechnical and agronomic parameters

\begin{tabular}{|c|c|c|c|c|c|c|}
\hline \multirow[t]{2}{*}{ Agricultural characterization of the systems ${ }^{\mathrm{a}}$} & \multicolumn{6}{|c|}{ Chronosequence of management in each year } \\
\hline & 1 & 2 & 3 & 4 & 5 & 6 \\
\hline PRP & Potato & Pasture & Pasture & Potato & Pasture & Pasture \\
\hline IP & Pasture & Pasture & Pasture & Pasture & Pasture & Pasture \\
\hline SPS & \multicolumn{6}{|c|}{$\begin{array}{l}\text { Permanent pasture of Pennisetum clandestinum with Acacia } \\
\text { decurrens and clover }\end{array}$} \\
\hline Zootechnical characterization $^{\mathrm{a}}$ & \multicolumn{2}{|c|}{ PRP } & \multicolumn{2}{|l|}{ IP } & \multicolumn{2}{|l|}{$\mathrm{SPS}^{\mathrm{b}}$} \\
\hline Type of pasture & \multicolumn{2}{|c|}{ Degraded } & \multicolumn{2}{|c|}{ Improved } & \multicolumn{2}{|c|}{ Productive } \\
\hline Type of management system & \multicolumn{2}{|c|}{ Extensive } & \multicolumn{2}{|c|}{ Intensive } & \multicolumn{2}{|c|}{ Semi-extensive } \\
\hline Animal genetics & \multicolumn{2}{|c|}{ Holstein } & \multicolumn{2}{|c|}{ Holstein } & \multicolumn{2}{|c|}{ Holstein } \\
\hline Stocking rate $\left(\mathrm{AU} \mathrm{ha} \mathrm{hr}^{-1} \mathrm{yr}^{-1}\right)^{\mathrm{c}}$ & \multicolumn{2}{|c|}{0.5} & \multicolumn{2}{|c|}{1.5} & \multicolumn{2}{|c|}{1.5} \\
\hline Production (liter of milk animal ${ }^{-1}$ day $^{-1}$ ) & \multicolumn{2}{|l|}{10} & \multicolumn{2}{|l|}{18} & \multicolumn{2}{|l|}{17} \\
\hline $\mathrm{L}$ of milk ha ${ }^{-1} \mathrm{yr}^{-1}$ & \multicolumn{2}{|c|}{1825} & \multicolumn{2}{|c|}{9855} & \multicolumn{2}{|l|}{9308} \\
\hline
\end{tabular}

${ }^{a}$ Extracted from Guerrero (1998), Bernal (1994), Solarte et al. (2006), Fedegan-Cipav (2010)

b Silvopastoral system combination of improved pasture of Pennisetum clandestinum and legumes with shrubs of Acacia decurrens at a density of 400 trees per hectare as living fence

c AU for 650 mature weights lactating cow $(\mathrm{kg})$

a stocking rate lower than that of intensive silvopastoral systems (Fedegan-Cipav 2010; Naranjo et al. 2012) and rotational grazing of animals every 60 days (Table 1).

\subsection{Emission sources and sinks and amounts of agricultural supplies}

Table 2 summarizes the sources and potential sinks of the most important GHG emissions $\left(\mathrm{CO}_{2}, \mathrm{CH}_{4}\right.$ and $\left.\mathrm{N}_{2} \mathrm{O}\right)$ associated with each of the production systems considered in the methodological approach of this study. Additionally, the data on the agricultural supplies and fuel consumption due to agricultural activities conducted in each assessed scenario are listed in Table 3.

\subsection{The emission factors}

\subsection{1 $\mathrm{CH}_{4}$ and $\mathrm{N}_{2} \mathrm{O}$ from enteric fermentation and manure management}

To estimate the emission associated with $\mathrm{CH}_{4}$ by enteric fermentation, the equations proposed by the IPCC Tier 2 methodology [IPCC (2006); Chapter 10, Table 10.3] were applied to estimate daily gross energy intake for dairy cattle with 412, 302 and $298 \mathrm{MJ}$ head $^{-1}$ day $^{-1}$ for milk production in PRP, IP and SPS scenarios, respectively. Gross energy depends on the digestible energy ( $\mathrm{DE} \%$ ) of the food considered in our study as 65 , 70 and $72 \%$ for PRP, IP and SPS, respectively, and that produced in a $\mathrm{CH}_{4}$ enteric emission factor of 90, 79 and $59 \mathrm{~kg} \mathrm{CH}_{4}$ head $^{-1}$ year $^{-1}$ for PRP, IP and SPS, respectively. 
Table 2 Emission sources and respective greenhouse gas considered for each evaluated agricultural system: conventional agriculture (PRP), improved pasture (IP) and silvopastoral system (SPS) in the Andean region of Colombia

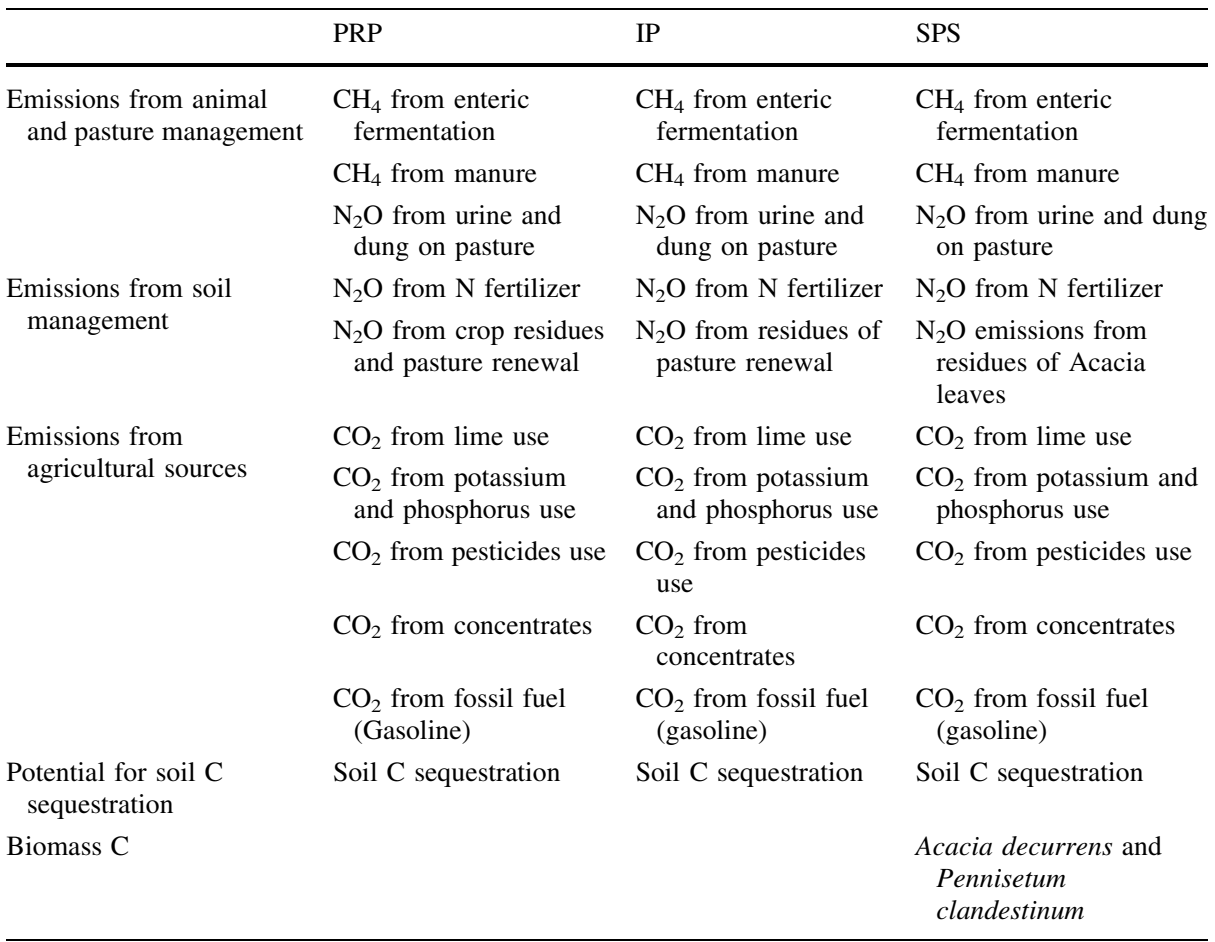

$\mathrm{CH}_{4}$ emission derived from manure management was based on the estimation of the amounts of volatile solid (VS) excretion in manure, which were considered in the present study as 5.3, 5.1 and $4.7 \mathrm{~kg} \mathrm{DM} \mathrm{head}{ }^{-1} \mathrm{day}^{-1}$ for PRP, IP and SPS, respectively. These also resulted in distinguished methane emission factor associated with manure for each of the studied scenarios as $1.5,1.4$ and $1.3 \mathrm{~kg} \mathrm{CH}_{4}$ head $^{-1}$ year $^{-1}$ for PRP, IP and SPS, respectively. Values of VS were estimated based on feed intake and digestibility of food.

$\mathrm{N}_{2} \mathrm{O}$ emission associated with manure management was estimated by also taking into account the annual average nitrogen excretions as $18.4,75.1$ and $40 \mathrm{~kg} \mathrm{head}^{-1}$ year $^{-1}$ for PRP, IP and SPS, respectively, resulting in emission factors of $0.4,4.3$ and $2.3 \mathrm{~kg} \mathrm{~N}_{2} \mathrm{O}$ head $^{-1}$ year $^{-1}$ for the respective scenarios.

\section{4 $\mathrm{N}_{2} \mathrm{O}$ from soil management and $\mathrm{CO}_{2}$ from agricultural activities}

The direct and indirect emissions from nitrogen fertilizer application and above-ground residues were estimated by using IPCC (2006) methodology. The emission factor regarding lime was assumed as $0.477 \mathrm{~kg} \mathrm{CO}_{2}$-eq $\mathrm{kg}^{-1}$ (dolomite) in PRP, IP and SPS scenarios (IPCC 2006). The emission factors associated with the manufacturing, transport, and storage of potassium and phosphate fertilizers were $0.2 \mathrm{~kg} \mathrm{CO}_{2}$-eq kg-1 for phosphorus and $0.15 \mathrm{~kg} \mathrm{CO}_{2}$-eq $\mathrm{kg}^{-1}$ for potassium, as proposed by Lal (2004). For pesticides, the 
Table 3 Annual amounts of agricultural supplies and fossil fuel use (medium values for a 6-year production cycle), considered for each agricultural system

\begin{tabular}{llll}
\hline Supplies & Amounts & \\
\cline { 2 - 4 } & PRP & IP & SPS \\
\hline $\mathrm{N}$ synthetic fertilizer $\left(\mathrm{kg} \mathrm{N} \mathrm{ha}^{\mathrm{a}} \mathrm{yr}^{-1}\right)$ & $65^{\mathrm{b}}$ & $120^{\mathrm{c}}$ & $50^{\mathrm{d}}$ \\
$\mathrm{N}$ organic fertilizer $\left(\mathrm{kg} \mathrm{N} \mathrm{ha}^{-1} \mathrm{yr}^{-1}\right)$ & 30 & - & - \\
$\mathrm{N}$ from crop residues $\left(\mathrm{kg} \mathrm{N} \mathrm{ha}^{-1} \mathrm{yr}^{-1}\right)$ & 67 & 102 & 22 \\
Lime $\left(\mathrm{kg} \mathrm{ha}^{-1} \mathrm{yr}^{-1}\right)$ & $666^{\mathrm{e}}$ & $1000^{\mathrm{f}}$ & $166^{\mathrm{g}}$ \\
$\mathrm{P}$ fertilizers $\left(\mathrm{kg} \mathrm{ha}^{-1} \mathrm{yr}^{-1}\right)$ & $40^{\mathrm{b}}$ & $24^{\mathrm{c}}$ & $60^{\mathrm{h}}$ \\
$\mathrm{K}^{\mathrm{h}}$ fertilizers $\left(\mathrm{kg} \mathrm{ha}^{-1} \mathrm{yr}^{-1}\right)$ & $30^{\mathrm{b}}$ & $50^{\mathrm{d}}$ & $50^{\mathrm{h}}$ \\
Concentrated $\left(\mathrm{kg} \mathrm{ha}^{-1} \mathrm{yr}^{-1}\right)$ & 406 & 2190 & 2068 \\
Pesticides $\left(\mathrm{kg} \mathrm{ha}^{-1} \mathrm{yr}^{-1}\right)$ & 24 & 10 & - \\
Gasoline $\left(\mathrm{L} \mathrm{ha}^{-1} \mathrm{yr}^{-1}\right)$ & 282 & 93 & 53 \\
\hline
\end{tabular}

PRP conventional agriculture, $I P$ improved pasture, $S P S$ silvopastoral system)

${ }^{a}$ Data from Guerrero (1998) and Bernal (1994)

b $1500 \mathrm{~kg} \mathrm{13-26-6} \mathrm{PRP} \mathrm{(Guerrero} \mathrm{1998),} \mathrm{during} 2$ years (potato seeding) in cycle of 6 years

c $400 \mathrm{~kg} \mathrm{ha}^{-1} \mathrm{yr}^{-1}$ of 30-6-0 (Guerrero 1998) each year in IP

${ }^{\mathrm{d}} 50 \mathrm{~kg} \mathrm{ha}^{-1} \mathrm{yr}^{-1}$ (Guerrero 1998), $50 \mathrm{~kg} \mathrm{ha}^{-1} \mathrm{yr}^{-1}$ (Guerrero 1998)

e $2 \mathrm{t} \mathrm{ha}^{-1}$ before of potatoes seeding

f $1 \mathrm{t} \mathrm{ha}^{-1} \mathrm{yr}^{-1}$ (Guerrero 1998)

g $1 \mathrm{tha}^{-1}$ in all cycle

${ }^{\mathrm{h}}$ For native pastures in consortium with clover. Some of the amounts presented were obtained directly in the production locations

emission factor depends on the type of pesticide applied (Helsel 1992) to control pests and diseases in PRP and IP scenarios (Lal 2004). The amount of commercial feed concentrate used in each of the systems corresponds to $1 \mathrm{~kg}$ per $4.5 \mathrm{~L}$ of milk produced (Bernal 1994). The emission factor used was $0.59 \mathrm{~kg} \mathrm{CO}_{2}$-eq kg ${ }^{-1}$ of concentrate (Hassan 2011).

The fossil fuel used in the agricultural operations (e.g., machinery) in the Andean region of Colombia is usually gasoline, with an emission factor under tropical conditions estimated to be $2.33 \mathrm{~kg} \mathrm{CO}_{2}$-eq L ${ }^{-1}$ of gasoline (Hassan 2011). All emissions values were converted into $\mathrm{CO}_{2}$ equivalent following the individual global warming potentials for a period of 100 years, using 1 for $\mathrm{CO}_{2}, 25$ for $\mathrm{CH}_{4}$ and 298 for $\mathrm{N}_{2} \mathrm{O}$ (IPCC 2007).

\subsubsection{Soil and biomass carbon pools}

Reference value for the soil carbon stock in extensive pastures of the Andes, Colombia, was based on the data from Silva et al. (2010), which is $147.9 \mathrm{Mg} \mathrm{ha}^{-1}$ in the top $30-\mathrm{cm}$ layer. This value is considered as our baseline for soil carbon stock in extensive pasture, and it is used for estimating changes in soil carbon stocks by converting from extensive pasture to PRP, IP and SPS scenarios (Fig. 2). The ratio of gains/losses of soil carbon in the evaluated scenarios was estimated by using a specific methodology proposed by IPCC (2006), which takes into account the factors related to soil management practices: land use (FLU), tillage practices (FMG) and residue inputs (FI) for a time period of 20 years (IPCC 2006). In addition to the intensity of management adopted (for instance, high, medium and 


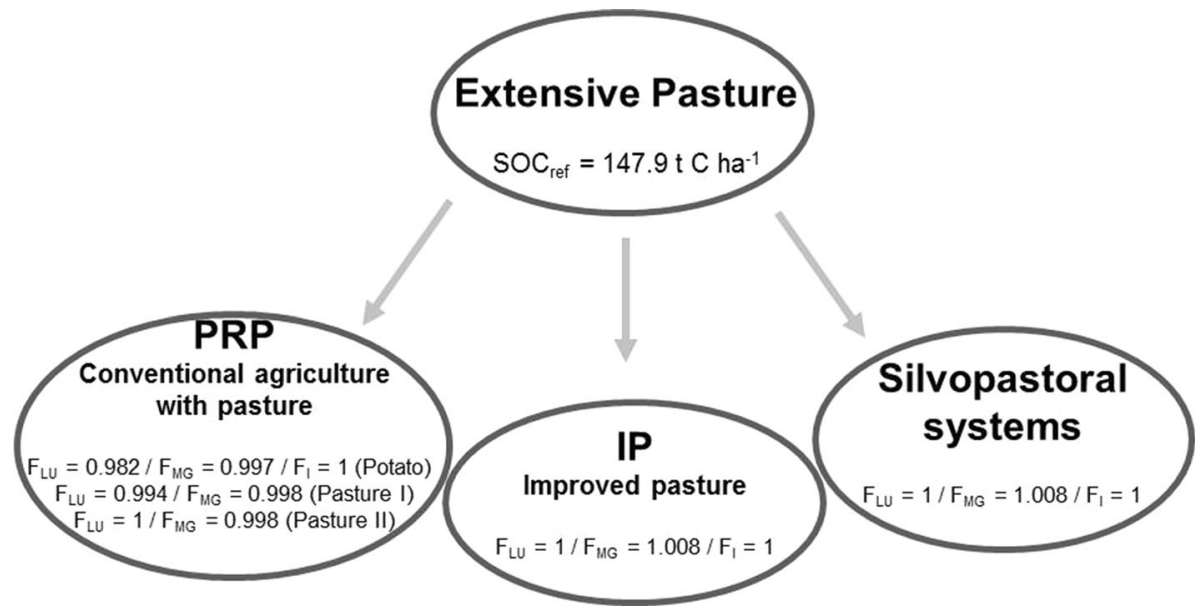

Fig. 2 Representation of the main aspects (SOC reference and stock change factors) considered for estimations of soil $\mathrm{C}$ gain/losses (changes) in the conversion from extensive pasture to other studied scenarios: conventional agriculture (PRP), improved pasture (IP) and silvopastoral system (SPS)

low inputs), these factors also take into account climate and soil type in the specific region. The accumulation rate of carbon in biomass was estimated in SPS only. Based on IPCC (2006) methodology, the increase in biomass carbon stock was assumed to be $4.5 \mathrm{Mg} \mathrm{C}$ $\mathrm{ha}^{-1}$ year $^{-1}$, considering the wood component for Acacia spp. in South America.

\section{Results and discussion}

\subsection{Greenhouse gas emissions}

The highest emissions for all production systems were estimated to be produced from $\mathrm{CH}_{4}$ due to enteric fermentation, with 1125,2963 and $2213 \mathrm{~kg} \mathrm{CO}_{2}$-eq ha ${ }^{-1}$ year $^{-1}$, corresponding to 31,38 and $45 \%$ of the total GHG emission in PRP, IP and SPS scenarios, respectively (Table 4 and Fig. 3). The second highest emission source varied among the assessed scenarios. In PRP, $\mathrm{CO}_{2}$ related to fossil fuel use was the second highest emission source, followed by $\mathrm{N}_{2} \mathrm{O}$ from cattle dung and urine in IP, and $\mathrm{CO}_{2}$ from concentrates used to feed cattle in SPS. These emissions correspond to 18,17 and $25 \%$ of the total GHG emission in PRP, IP and SPS scenarios, respectively (Fig. 3). The third higher emission sources were also dissimilar among the scenarios studied. The sources were associated with $\mathrm{N}_{2} \mathrm{O}$ emissions from synthetic fertilizer in PRP and $\mathrm{N}_{2} \mathrm{O}$ emission from dung and urine in IP and SPS scenarios, corresponding to 11, 16.9 and $14 \%$ of the total emissions in PRP, IP and SPS scenarios, respectively.

The total GHG emission differed mostly between IP and PRP scenarios, with the highest and lowest emissions being 7711 and $3684 \mathrm{~kg} \mathrm{CO}_{2}$-eq ha ${ }^{-1}$ year $^{-1}$, respectively. This difference of $4027 \mathrm{~kg} \mathrm{CO}_{2}$-eq $\mathrm{ha}^{-1}$ year $^{-1}$ is primarily due to the varying cattle intensity in the production systems $(0.5 \times 1.5$ stocking rate; Table 1$)$, as this comes mostly from $\mathrm{CH}_{4}$ emission by enteric fermentation and $\mathrm{CO}_{2}$ from concentrates in cattle feed. With an intermediate total GHG emission, SPS scenario resulted in $4878 \mathrm{~kg} \mathrm{CO}_{2}$-eq ha ${ }^{-1}$ year $^{-1}$, which is lesser than that of IP but higher than PRP total emissions. 
Table 4 GHG emissions related to conventional agriculture (PRP), improved pasture (IP) and silvopastoral system (SPS) in the Andean region of Colombia, according to each emission source $\left(\mathrm{kg} \mathrm{CO}_{2}\right.$ eq ha $\left.{ }^{-1} \mathrm{yr}^{-1}\right)$ considered herein

GHG emissions related to the stocking rates in each agricultural system, 0.5 AU ha ${ }^{-1} \mathrm{yr}^{-1}$ in PRP, 1.5 AU ha ${ }^{-1} \mathrm{yr}^{-1}$ in IP and SPS. Mean values for 6-year cycle

$\begin{array}{llll}\text { Sources } & \text { PRP } & \text { IP } & \text { SPS }\end{array}$

$\mathrm{CH}_{4}$ and $\mathrm{N}_{2} \mathrm{O}$ emissions from animal and pasture management

$\begin{array}{lrrl}\mathrm{CH}_{4} \text { from enteric fermentation } & 1125 & 2963 & 2213 \\ \mathrm{CH}_{4} \text { from manure management } & 19 & 53 & 49 \\ \mathrm{~N}_{2} \mathrm{O} \text { from dung and urines on pasture } & 105 & 1286 & 686\end{array}$

$\mathrm{N}_{2} \mathrm{O}$ emissions from soil management

$\begin{array}{llll}\mathrm{N}_{2} \mathrm{O} \text { emissions from synthetic } \mathrm{N} \text { fertilizer } & 403 & 745 & 310\end{array}$

$\mathrm{N}_{2} \mathrm{O}$ from organic fertilizer

200

$\begin{array}{llll}\mathrm{N}_{2} \mathrm{O} \text { from above-ground residues } & 384 & 585 & 126\end{array}$

$\mathrm{CO}_{2}$ from agricultural activities

\begin{tabular}{lrrl}
$\mathrm{CO}_{2}$ from lime use & 317 & 476 & 79 \\
$\mathrm{CO}_{2}$ from potassium and phosphorus use & 46 & 45 & 71 \\
$\mathrm{CO}_{2}$ from concentrates & 240 & 1292 & 1220 \\
$\mathrm{CO}_{2}$ from pesticides use & 188 & 50 & - \\
$\mathrm{CO}_{2}$ from due fossil (Gasoline) & 657 & 216 & 124 \\
Total GHG emissions & 3684 & 7711 & 4878 \\
\hline
\end{tabular}

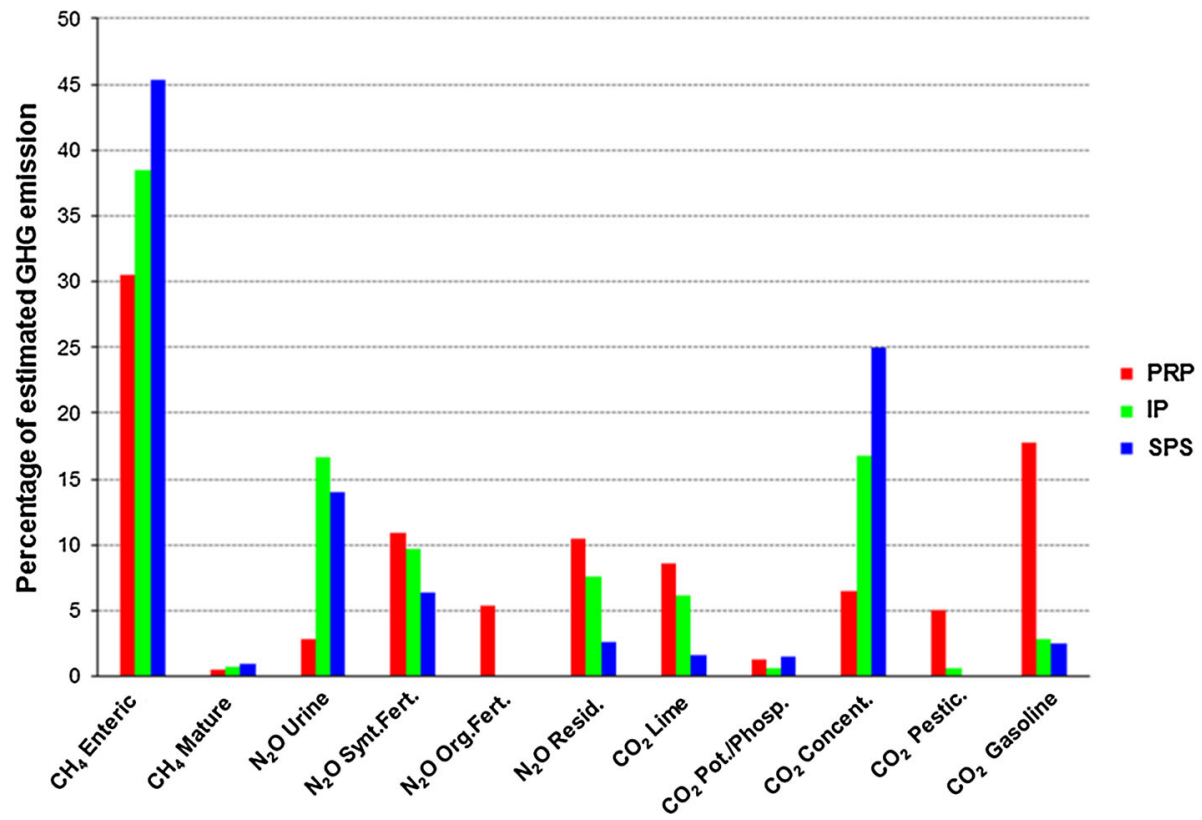

Fig. 3 Percentage of estimated GHG emissions for each source of the assessed production scenarios: conventional agriculture (PRP), improved pasture (IP) and silvopastoral system (SPS)

Hence, a lower $\mathrm{CH}_{4}$ emission from enteric fermentation per head would be achieved in IP rather than in PRP, due to a better feed digestibility found in improved pasture conditions, as listed in Table 4. This assertion is supported by several studies (Primavesi et al. 2004, Figueiredo et al. 2017b), which showed that the efficiency of grass utilization, 
individual animal performance and production per hectare is largely determined by improved management practices.

When comparing SPS and IP emission sources, it could be observed that the reduction of the total emissions results from the different sources. For instance, our calculation of $\mathrm{CH}_{4}$ emission from enteric fermentation in the PRP scenario is related to low efficiency of grass utilization, rotational grazing practices with potatoes, grass digestibility of $65 \%$, and gross energy of $412 \mathrm{MJ}_{\text {head }}^{-1}$ day $^{-1}$, which resulted in an emission factor of $90 \mathrm{~kg} \mathrm{CH}_{4}$ head $^{-1}$ year $^{-1}$ that was associated with a stocking rate of $0.5 \mathrm{AU} \mathrm{ha}^{-1}$ year ${ }^{-1}$, resulting in $1125 \mathrm{~kg} \mathrm{CO}_{2}$-eq ha ${ }^{-1}$ year $^{-1}$ (Table 4). $\mathrm{CH}_{4}$ emissions from enteric fermentation due to animal and pasture management of L. multiflorum for milk production in the IP scenario were related to intensive grazing, higher grass digestibility of $72 \%$, and gross energy of $302 \mathrm{MJ} \mathrm{head}^{-1} \mathrm{day}^{-1}$, which accounted for a higher share of emissions of $2963 \mathrm{~kg} \mathrm{CO}_{2}$-eq $\mathrm{ha}^{-1}$ year $^{-1}(47 \%)$ (Table 4), and was even related to a lower emission factor of $79 \mathrm{~kg}$ $\mathrm{CH}_{4}$ head $^{-1}$ year $^{-1}$, but was influenced by higher stocking rate of $1.5 \mathrm{AU} \mathrm{ha}{ }^{-1}$ year $^{-1}$.

From the SPS scenario, the adoption of animal and pasture management of $P$. clandestinum and $T$. repens with browsing of leaves of $A$. decurrens for milk production with better feed digestibility of $75 \%$ and gross energy of $298 \mathrm{MJ} \mathrm{head}^{-1}$ day $^{-1}$ resulted in significantly lower emissions of $53 \mathrm{~kg} \mathrm{CH}_{4}$ head $^{-1}$ year $^{-1}$. When associated with a stocking rate of $1.5 \mathrm{AU} \mathrm{ha}^{-1}$ year $^{-1}$, it corresponded to an emission of $2213 \mathrm{~kg} \mathrm{CO}_{2^{-}}$ eq ha ${ }^{-1}$ year ${ }^{-1}$ (Table 4). Our results point out to a high contribution of $\mathrm{CH}_{4}$ from enteric fermentation in milk production systems in the Andean zone of Colombia and the importance to the management of improved pasture areas, resulting in higher feed digestibility and lower associated GHG emissions. In addition, Apraez et al. (2012) showed the impact of a diet with A. decurrens rich in tannins on the reduction of enteric methane emissions. A similar trend was observed by Hess et al. (2002), who indicated tannins in many legume species to be associated with reduction of methane production (e.g., up to $50 \%$ ) compared with traditional single pasture diet.

\subsection{Potential C sinks}

The estimations of potential sinks either in soils or in biomass for all assessed scenarios are presented in Fig. $4\left(\mathrm{~kg} \mathrm{CO}_{2}\right.$-eq ha ${ }^{-1}$ year $\left.^{-1}\right)$ considering a 6-year cycle. Our estimation indicates a reduction in soil carbon stock in extensive pasture of PRP system from 147.9 to 138.95 $\mathrm{Mg} \mathrm{C} \mathrm{ha}^{-1}$, which results in a soil carbon loss of $8.95 \mathrm{Mg} \mathrm{C} \mathrm{ha}^{-1}$ in the 6 -year period. Mean annual value of this loss, when converted into $\mathrm{CO}_{2}$-eq, would represent an emission of $5471 \mathrm{~kg} \mathrm{CO}_{2}$-eq ha ${ }^{-1}$ year $^{-1}$ (Fig. 4).

On the other hand, a conversion of extensive pasture to IP system resulted in carbon stock ranging from 147.9 to $154.99 \mathrm{Mg} \mathrm{C} \mathrm{ha}^{-1}$, which represents a soil carbon sink of $7.09 \mathrm{Mg} \mathrm{C} \mathrm{ha}{ }^{-1}$ over the 6-year cycle. This gain corresponds to a potential for soil carbon accumulation of $4342 \mathrm{~kg} \mathrm{CO}_{2}$-eq ha ${ }^{-1}$ year $^{-1}$. Likewise, the SPS scenario presented the same potential for soil carbon accumulation of $7.09 \mathrm{Mg} \mathrm{C}^{-1}$ (6 years), which resulted in the same $\mathrm{CO}_{2}$ sink value. The system that presented the better potential for GHG mitigation was SPS. As according to our results, it has, in addition to the potential for soil carbon accumulation, the trees $A$. decurrens that have the potential to absorb as much as $16,500 \mathrm{~kg} \mathrm{CO}_{2}$-eq ha ${ }^{-1}$ year $^{-1}$ (Fig. 4). 


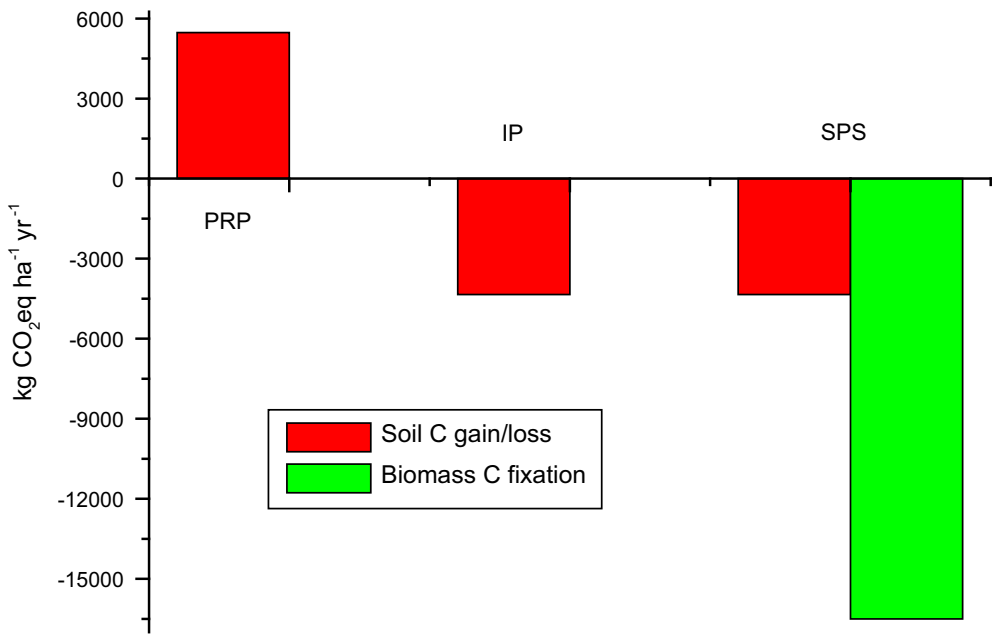

Fig. 4 Potential $\mathrm{C}$ sinks or emissions from soils and biomass $\left(\mathrm{kg} \mathrm{CO}_{2} \mathrm{eq} \mathrm{ha} \mathrm{ha}^{-1} \mathrm{yr}^{-1}\right)$ for each evaluated production scenario: conventional agriculture (PRP), improved pasture (IP) and silvopastoral system (SPS)

\subsection{Discussion on the greenhouse gas balance, considering total emission and potential sinks}

In a recent report, FAO (2010) presented intermediate levels of GHG emissions between 3 and $5 \mathrm{~kg} \mathrm{CO}_{2}$-eq kg ${ }^{-1}$ of fat- and protein-corrected milk for South America. The world average would represent a value of carbon footprint associated with milk production as close to $2.4 \mathrm{~kg} \mathrm{CO}_{2}$-eq $\mathrm{kg}^{-1}$ of milk. In this study, however, only the GHG balance was considered for the assessed production systems instead of carbon footprint of milk production. The results of GHG balance are listed in Table 5, considering the total GHG emissions as well as the potential for soil carbon gain/loss and biomass carbon fixation. The PRP scenario presented the lowest GHG emission ( $3684 \mathrm{~kg} \mathrm{CO}_{2}$-eq ha ${ }^{-1}$ year $^{-1}$ ), but also presented the lowest milk production $\left(1825 \mathrm{~L} \mathrm{ha}^{-1}\right.$ year $\left.^{-1}\right)$. Although potato is produced in this scenario, further emissions would be expected according to our

Table 5 GHG balance (in $\mathrm{kg} \mathrm{CO}_{2} \mathrm{eq} \mathrm{ha}^{-1} \mathrm{yr}^{-1}$ ) considering the total GHG emissions and the respective potential for soil carbon accumulation and biomass carbon fixation of each evaluated scenario (PRP, IP and SPS)

\begin{tabular}{llll}
\hline Components & PRP & IP & SPS \\
\hline Total GHG emissions $_{\text {Soil C gain/loss }}^{\mathrm{a}}$ & 3684 & 7711 & 4878 \\
Biomass C fixation $^{\mathrm{b}}$ & 5471 & -4342 & -4342 \\
GHG balance & - & - & $-16,500$ \\
\hline & 9155 & 3369 & $-15,964$
\end{tabular}

PRP conventional agriculture with pastures of Pennisetum clandestinum in rotation with potatoes, IP improved pasture of Lolium multiflorum, SPS silvopastoral systems represented by pastures of Pennisetum clandestinum in consortium with Acacia decurrens and Trifolium repens. Mean values for a 6-year cycle

${ }^{a}$ Negative values indicate soil carbon accumulation and positive soil $\mathrm{C}$ losses (converted into $\mathrm{CO}_{2} \mathrm{eq}$ )

${ }^{\mathrm{b}}$ Negative values refer to gain in biomass $\mathrm{C}$ reservoirs 
estimations because of soil carbon losses $\left(5471 \mathrm{~kg} \mathrm{CO}_{2}\right.$-eq ha ${ }^{-1}$ year $\left.^{-1}\right)$, leading to the highest GHG balance of $9155 \mathrm{~kg} \mathrm{CO}_{2}$-eq ha ${ }^{-1}$ year $^{-1}$ in relation to the other assessed scenarios of milk production.

The IP scenario resulted in the highest GHG emission (7711 $\mathrm{kg} \mathrm{CO}_{2}$-eq ha ${ }^{-1}$ year $^{-1}$ ), but also presented the highest milk productivity $\left(9855 \mathrm{~L} \mathrm{ha}^{-1} \mathrm{year}^{-1}\right)$ and an additional potential for soil carbon accumulation equivalent to $4342 \mathrm{~kg} \mathrm{CO}_{2}$-eq ha ${ }^{-1}$ year $^{-1}$. In this scenario, total GHG emissions were partially offset by the soil carbon accumulation and therefore resulted in GHG balance of $3369 \mathrm{~kg} \mathrm{CO}_{2}$-eq ha ${ }^{-1}$ year ${ }^{-1}$. Comparing the three assessed scenarios, the results showed that SPS merged two important strategies to mitigate the GHG emissions from milk production, such as the potentials for soil carbon accumulation (4342 $\mathrm{kg} \mathrm{CO}_{2}$-eq ha ${ }^{-1}$ year $^{-1}$ ) and for biomass carbon accumulation $(16,500 \mathrm{~kg}$ $\mathrm{CO}_{2}$-eq $\mathrm{ha}^{-1}$ year $^{-1}$ ), which is even higher than the expected for soil carbon accumulation. Both soil and biomass carbon sinks in the SPS scenario completely offset the total GHG emissions of milk production and thereby resulted in GHG balance of $-15,964 \mathrm{~kg} \mathrm{CO}_{2^{-}}$ eq ha $^{-1}$ year $^{-1}$ (Table 5).

Despite the huge potential for mitigation of GHG emissions, especially in the SPS scenario, it is important to highlight that soil carbon accumulation could be lost rapidly depending on the soil management decision taken for these sites. For instance, La Scala et al. (2006) reported significant emissions induced by intensive tillage operations in southern Brazil. Additionally, the use of Acacia wood after harvest, or even leaving those as living fence, can effectively contribute for the potential of biomass carbon fixation to turn into a carbon pool with prolonged longevity, or sequestration.

\section{Conclusions}

The conversion of conventional agriculture areas to a more intensive pasture or silvopastoral system for milk production increased total GHG emission per unit area, but also reduced the GHG emission per unit of product ( $\mathrm{kg} \mathrm{CO}_{2}$ eq per $\mathrm{kg}$ of milk), as a result of a more efficient production system and higher yields. Although the IP has showed a higher milk production compared to all assessed systems, the SPS presented the lowest GHG emission per unit of milk produced. Silvopastoral system represented by pastures of $P$. clandestinum in combination with $A$. decurrens and $T$. repens (SPS) showed to be a promising integrated system that has the potential to offset GHG emissions associated with milk production, which could contribute for the development of a more sustainable milk production system. However, it is also important that these management systems be considered along with economic and social aspects. This study supports the conclusion that the intensification of dairy cattle production leads to a reduction in GHG emissions per unit of product in the Andean zone of Colombia. Further, the great advantage of intensification is not only associated with GHG mitigation, but also in the reduction in land needed to produce the same quantity of product. Our findings appear as good indicator of the main sources of GHG emission in the dairy cattle production in both extensive and intensive systems in Colombia and could contribute to a better understanding of the Colombian milk production chain in the context of sustainability. However, there exists a need for additional experimental studies to further comprehend the potential carbon sinks in soils and biomass in the Andean region of Colombia. 


\section{References}

Aguilar, O. X., Moreno, B. M., Pabón, M. L., \& Carulla, J. E. (2009). Efecto del consumo de kikuyo (Pennisetum clandestinum) o raigrás (Lolium hibridum) sobre la concentración de ácido linoléico conjugado y el perfil de ácidos grasos de la grasa láctea. Livestock Research for Rural Development, $24,1-12$.

Apraez, J. E., Delgado, J. M., \& Narvaez, J. P. (2012). Composición nutricional, degradación in vitro y potencial de producción de gas, de herbáceas, arbóreas y arbustivas encontradas en el trópico alto de Nariño. Livestock Research for Rural Development, 24, 1-10.

Bernal, J. (1994). Algunas características agronómicas de los ryegrass. Banco Ganadero. Pastos y Forrajes para Colombia (3rd ed.). Bogotá: Banco Ganadero.

Boul, H. L., Garnham, M. L., Hucker, D., Baird, D., \& Aislabie, J. (1994). Influence of agricultural practices on the levels of DDT and its residues in soil. Environmental Science and Technology, 28, 1397-1402.

Corazza, E. J., Silva, J. E., Resk, D. V. S., \& Gomes, A. C. (1999). Behavior of different management systems as a source or sink of $\mathrm{C}-\mathrm{CO}_{2}$ in relation to cerrado type vegetation. Revista Brasileira de Ciência do Solo, 23, 425-432.

Correa, C. H. J., Pabón, R. M. L. Y., \& Carulla, F. J. E. (2008). Valor nutricional del pasto kikuyo (Pennisetum clandestinum Hoechst Ex Chiov.) para la producción de leche en Colombia (Una revisión). Livestock Research for Rural Development, 20, 1-10.

Costa, C., Papatheodorou, E. M., Monokrousos, N., \& Stamou, G. P. (2015). Spatial variability of soil organic $\mathrm{C}$, inorganic $\mathrm{N}$ and extractable $\mathrm{P}$ in a Mediterranean grazed area. Land Degradation and Development, 26, 103-109.

[FAO] Food and Agriculture Organization. (2010). Grasslands: Enabling their potential to contribute to greenhouse gas mitigation. Rome: Food and Agriculture Organization of the United Nations (FAO).

[FEDEGAN-CIPAV] Federaciòn Nacional de Ganaderos. (2010). Informe del Proyecto: Evaluación Técnica, Económica-Financiera y Ambiental de Sistemas Silvopastorales Intensivos con Leucaena leucocephala y pastos mejorados en el Valle del Río Cesar. Cali: Federaciòn Nacional de Ganaderos.

Figueiredo, E. B., Jayasundara, S., Bordonal, R. O., Berchielli, T. T., Reis, R. A., Wagner-Riddle, C., et al. (2017a). Greenhouse gas balance and carbon footprint of beef cattle in three contrasting pasturemanagement systems in Brazil. Journal of Cleaner Production, 142, 420-431.

Figueiredo, E. B., Panosso, A. R., Bordonal, R. O., Teixeira, D. D. B., Berchielli, T. T., \& La Scala, N., Jr. (2017b). Soil $\mathrm{CO}_{2}-\mathrm{C}$ emissions and correlations with soil properties in degraded and managed pastures in Southern Brazil. Land Degradation \& Development, 28, 1263-1273.

Giraldo, V., \& Bolivar, G. (2004). Evaluación de un sistema silvopastoril de Acacia decurrens asociada con pasto kikuyo Pennisetum clandestinum, en clima frío de Colombia. Bogotá: Conservación de la naturaleza y recursos de la tierra.

Giraldo, A., Zapata, M., \& Montoya, E. (2008). Captura y flujo de carbono en un sistema silvopastoral de la zona andina Colombiana. Archivos Latinoamericanos de Producción Animal, 16, 241-245.

Grainger, C., Clarke, T., Auldist, M. J., Beauchemin, K. A., McGiin, S. M., Waghorn, G. C., et al. (2009). Mitigation of greenhouse gas emissions from dairy cows fed pasture and grain through supplementation with Acacia mearnsii tannins. Canadian Journal of Forest Research, 89, 241-251.

Guerrero, R. (1998). Fertilización de cultivos en clima frio. Bogotá: Sáenz y Cía. Ltda.

Hassan, J.A. (2011). El ciclo de vida en la producción de leche y la dinámica de las emisiones de gases de efecto invernadero en fincas doble propósito de la península de Azuero. Doctoral Thesis, Centro Agronómico Tropical de Investigación y Enseñanza, Turrialba.

Helsel, Z. R. (1992). Energy and alternatives for fertilizer and pesticide use. In R. C. Fluck (Ed.), Energy in farm production (pp. 177-201). Amsterdam: Elsevier.

Hess, H., Monsalve, L., Carulla, J., Lascano, C., Díaz, T., Kreuzer, M. (2002). In vitro evaluation of the effect of Sapindus saponaria on methane release and microbial populations (1.4.1). $<$ http://www.ciat. cgiar.org/forrajes/pdf/output1_2002.pdf>. Acess: 13 January 2015.

[IPCC] Intergovernmental Panel on Climate Change. (2006). Guidelines for national greenhouse gas inventories. The intergovernmental panel on climate change. Institute for Global Environmental Strategies, Kanagawa. <http://www.ipcc-nggip.iges.or.jp/support/Primer_2006GLs.pdf>. Access: 24 March 2014.

[IPCC] Intergovernmental Panel on Climate Change. (2007). Climate change. The physical science basis, contribution of working group I to the fourth assessment report of the IPCC. Cambridge: Cambridge University Press, Cambridge. <http://www.ipcc.ch/publications_and_data/publications_ipcc_fourth_ assessment_report_wg1_report_the_physical_science_basis.htm>. Access: 20 April 2014.

Köppen, W. (1948). Climatologia: Con um estúdio de los climas de la Tierra. Pánuco: Fondo de Cultura Economica. 
La Scala, N., Bolonhezi, D., \& Pereira, G. T. (2006). Short-term soil $\mathrm{CO}_{2}$ emission after conventional and reduced tillage of a no-till sugar cane area in southern Brazil. Soil and Tillage Research, 91, 244-248.

La Scala, N. Jr., De Figueiredo, E. B., \& Panosso, A. R. (2012). On the mitigation potential associated with atmospheric $\mathrm{CO}_{2}$ sequestration and soil carbon accumulation in major Brazilian agricultural activities. Brazilian Journal of Biology, 72, 775-785.

Lal, R. (2004). soil carbon sequestration to mitigate climate change. Geoderma, 123, 1-22.

McGrath, J. A., Penno, J. W., Macdonald, K. A., \& Carter, W. A. (1998). Using nitrogen fertilizer to increase dairy farm profitability. Proceedings-New Zealand Society of Animal Production, 58, $117-120$.

Medina, M., Orozco, H., \& Diaz, M. C. (2008). Establecimiento de un Sistema Silvopastoril mediante las especies Alnus acuminata H.B.K. y Acacia decurrens Willd y respuesta al empleo de organismos rizósfericos en San Pedro (Antioquia). Livestock Research for Rural Development, 20, 1-9.

Naranjo, J. F., Cuartas, C. A., Murgueitio, E., Chará, J., \& Barahona, R. (2012). Balance de gases de efecto invernadero en sistemas silvopastoriles intensivos con Leucaena leucocephala en Colombia. Livestock Research for Rural Development, 24, 1-12.

Noreña, J. M. (2011). Rehabilitación de praderas de kikuyo Pennisetum clandestinum con equipos de labranza vertical. Medellín: Colanta Pecuaria.

Oenema, O., Velthof, G. L., Yamulki, S., \& Jarvis, S. C. (1997). Nitrous oxide emissions from grazed grassland. Soil use and Management, 13, 288-295.

Papanastasis, V. P., Bautista, S., Chouvardas, D., Mantzanas, K., Papadimitriou, M., Mayor, A. G., et al. (2015). Comparative assessment of goods and services provided by grazing regulation and reforestation in degraded Mediterranean Rangelands. Land Degradation \& Development, 28, 1178-1187.

Primavesi, O., Pedreira, M. S., Friguetto, R. T. S., Lima, M. A., Berchielli, T. T., Oliveira, S. G., et al. (2004). Manejo alimentar de bovinos leiteiros e sua relação com produção de metano ruminal. São Carlos: Embrapa Pecuária Sudeste.

Robertson, G. P., Paul, E. A., \& Harwood, R. R. (2000). Greenhouse gases in intensive agriculture: Contributions individual gases to the radiative forcing of atmosphere. Science, 289, 1922-1925.

Saggar, S., Giltrap, D. L., Li, C., \& Tate, K. R. (2007). Modelling nitrous oxide emissions from grazed grasslands in New Zealand. Agriculture, Ecosystems \& Environment, 119, 205-216.

Sanchez, L., \& Villaneda, E. (2009). Renovación y manejo de praderas en sistemas de producción de leche especializada en el trópico alto colombiano. Bogotá: Corpoica, Colciencias.

Silva, A., Menjivar, J., Alava, C., Gomez, H. (2010). Efecto de la fertilización con N, P y S sobre una pradera degradada de pasto kikuyo Pennisetum clandestinum Hoestch en Nariño, Colombia. In Proceedings of the XII International Congreso Ecuatoriano de La Ciencia del Suelo, Equador (pp. 1-10).

Silva, J. E., Resck, D. V. S., Corazza, E. J., \& Vivaldi, L. (2004). Carbon storage in clayey Oxisol cultivated pastures in the "Cerrado" region, Brazil. Agriculture, Ecosystems \& Environment, 103, 357-363.

Smith, P., Bustamante, M., Ahammad, H., Clark, H., Dong, H., Elsiddig, E. A., Haberl, H., Harper, R., House, J., Jafari, M., Masera, O., Mbow, C., Ravindranath, N. H., Rice, C. W., Robledo Abad, C., Romanovskaya, A., Sperling, F., \& Tubiello, F. (2014). Agriculture, forestry and other land use (AFOLU). In O. Edenhofer, R. Pichs-Madruga, Y. Sokona, E. Farahani, S. Kadner, K. Seyboth, A. Adler, I. Baum, S. Brunner, P. Eickemeier, B. Kriemann, J. Savolainen, S. Schlömer, C. von Stechow, T. Zwickel and J.C. Minx (Eds.), Climate change 2014: Mitigation of climate change. contribution of working group III to the fifth assessment report of the intergovernmental panel on climate change. Cambridge, United Kingdom and New York, NY, USA: Cambridge University Press.

Smith, P., Cotrufo, M. F., Rumpel, C., Paustian, K., Kuikman, P. J., Elliott, J. A., et al. (2015). Biogeochemical cycles and biodiversity as key drivers of ecosystem services provided by soils. Soil, 1, $665-685$.

Smith, K. A., Taggart, I. P., \& Tsuruta, H. (1997). Emissions of $\mathrm{N}_{2} \mathrm{O}$ and NO associated with nitrogen fertilization in intensive agriculture, and the potential for mitigation. Soil Use and Management, 13, 297-304.

Solarte, C., Martínez, A., \& Burgos, W. (2006). El TLC con estados unidos: efectos y retos para la cadena láctea de Nariño. Tendencias, 7, 101-120. 